\title{
RISK ANALYSIS IN CORPORATE FINANCIAL MODELLING
}

Péter Juhász $z^{1}$

\begin{abstract}
Models applied in corporate finance can typically use only one segment of our knowledge about the future: expected values. In the light of this, the final results do not reflect the uncertainty related to the input parameter values. Despite having several available tools to allude to the uncertainty we were forced to hide when we are presenting the results to the decision maker, this process and the interpretation of output data often include misunderstandings and mistakes. When providing an overview of the risk analysis toolkit, this article focuses on exploring such misunderstandings and mistakes and describes other risk factors which influence the outcome of the modelling process. Based on the literature review, it seems that a kind of conversion between different risks exits: theoretically more accurate models may be more sensitive to estimation errors of input parameters and set much higher requirements towards modellers.
\end{abstract}

JEL codes: $\mathrm{C} 6, \mathrm{D} 8, \mathrm{G} 17, \mathrm{G}_{32}$

Keywords: sensitivity analysis, scenario analysis, Monte Carlo simulation, evaluation

Decisions on corporate finance issues require information about the future, however, such information is usually far from being certain. Consequently, we can rely only on various forecasts and estimates. At the same time, almost none of the indicators and formulas supporting decisions in corporate finance use expected distributions or value ranges, but suppose the accurate knowledge of specific values. In view of the above, our expectations about the future usually have to be concentrated in one number (in most cases, in the expected value).

This article examines the available means of displaying the uncertainty about input parameters in the final result of calculations in spite of the above, supporting risk-conscious decision-making. Agreeing with the main message of the study

1 Péter Juhász, Associate Professor with habilitation at Corvinus University of Budapest. Email:peter.juhasz@uni-corvinus.hu. 
by Iván Bélyácz and Katalin Daubner published in this journal ${ }^{2}$, these techniques point out the significance of probability nowadays, not only in the field of investments pricing various financial products and banking seeking to calculate exposures, but also in corporate finance. The following part of the article provides an overview of the most frequently applied risk analysis tools in corporate finance, as well as the pitfalls of their use, partly based on my counselling and teaching experience.

\section{THE RISK FACTORS OF CORPORATE MODELLING}

Lukic (2017) provides a good overview of the corporate modelling process. He points out: professional literature has been dealing with the description of the future of companies since the 1930s, but it was the spread of computers that gave the real boost to development. He stresses: a good corporate financial model reflects (1) not only correct accounting relations, but also (2) the breakdown or reduction of the individual financial amounts to essential components (piece, unit price, interest, inflation) Moreover, (3) the modelled amounts should be associated with realia (machine-hours, employees), which requires precise knowledge of the given industry and corporate environment.

In view of these, we should realise that the models may have various errors and distortions: there might be uncertainty not just about the precise values of certain input parameters, but also about the aforementioned three relations, especially the last one. Based on the above, if we wanted to model the uncertainty of forecasts, in principle, it would not be enough to examine a single model with different input parameters, but we should also compare the results of models based on different logics simultaneously.

In practice, companies rarely do so. The members of an organisation widely accept uncertainty about input data, while many of them may consider the acknowledgement of uncertainty about a model's structure as the lack of competence. It is particularly interesting, as various regulatory systems at banks regard it as evident that exposure models lead to different results. The results are considered to be better or less acceptable depending on the complexity of the estimation model applied. Moreover, according to some views, mixed systems based on various models perform better when it comes to risk assessment (Mérö, 2018).

2 BéLYÁCZ, IvÁN - DAubNer, KATALin (2020): Logical probability, uncertainty, investment decisions. Did Keynes's have impact on economic thinking? Economy and Finance, 7(1), ???-???. 
On the other hand, Barakonyi (1999:82) points out: our various forecast processes can be incorrect for four reasons. The result may be distorted if 1 ) the complexity of the environment is not sufficiently taken into account, 2) quantification is on a weak basis, 3) our model is very sensitive to certain input factors and 4) the model lacks intentionality. The first and the last factor rather refer to the risk of selecting a model, while the two middle factors cover estimation risks.

Beaman et al. (2005) divide modelling errors into quantitative and qualitative errors. The first category includes mechanical (typing, reference), logical and omission errors. The latter group includes errors such as writing the values of variables into formulas instead of references, the lack of the model's clear manageability, the use of excessively complicated formulas, the lack of appropriate documentation or the failure to provide protection against overwriting in the case of formulas and background data.

If risk factors are classified by origin instead of format, in addition to 1) model building and 2) the estimation risk of input parameters, we should draw attention to another risk factor, 3 ) the expert conducting modelling. Despite the fact that the logical connections and input data are correct, it may be a problem if the modeller did not choose the appropriate model (e.g. the truth was overly simplified). Lukic (2017) stresses: it is no coincidence that the professional minimum of stock market analyses is often regulated by authorities and professional organisations such as the CFA Institute, which brings together chartered financial analysts. It is important to note that it depends on the modeller's abilities and expertise how complicated processes they can model with acceptable accuracy and an appropriate toolkit.

A study conducted by Adamczyk and Zbroszczyk (2017) provides a good example for this risk. $84.7 \%$ of the 224 Polish stock analyses examined by them used the free cash flow to the firm (FCFF) approach. However, only 68\% of these analyses applied different capital costs for different periods in compliance with the requirements in professional literature.

Examining accountancy students, Beaman et al. (2005) pointed out: those students who did not attend a special course in modelling made frequently modelling mistakes, especially planning mistakes, in spreadsheet programmes. At the same time of occurrence of such errors significantly decreased already after attending a modelling course for half a year. Practical education could reduce primarily the occurrence of omitting important elements, unnecessary duplications and incorporating fix values instead of references in formulas.

On the other hand, the omission of people from the process (e.g. their replacement by artificial intelligence) would not be a good solution. Lukic (2017) emphasises that adaptive expectations are clearly observable in different parameter 
forecasts, while variables are heuristic, robust and approximate in most cases. It may be the explanation for the fact that according to professional literature, manmade models perform better than simple statistical solutions built on a single methodology and a strong theoretical basis, such as time series analysis.

\section{SENSITIVITY AND BREAK-EVEN ANALYSES}

Based on the definition of operational research, "sensitivity analysis is an analytical procedure in the course of which the effect of changes in the values of the model's parameters on the optimal solution can be detected" (Ferenczi, 2006:66.). In corporate finance, searching for the optimal is rare, but the approach is similar. During sensitivity analysis, selecting one or two from the input parameters, we examine how a change in the input factor affects the value of one or more result variables.

A sensitivity analysis can be conducted for two purposes. 1) Similarly to operational research, we can examine to what extent the input parameter should be changed to enable us to change our decision based on the final result. This application is better known as break even analysis in corporate finance (Sener-Jenkins, 2016). The aim of the other approach is 2) to identify the key variables which considerably affect the result of the model. In order to achieve this goal, the possible extrema of these key variables have to be used as substitutes in the model.

As opposed to scenario analysis described below, sensitivity analysis does not examine the risk of the modelled strategy, but the risk posed by errors in the estimation of input parameters instead. Sensitivity analysis aims to reduce the production time of acceptably good models. The infinitely accurate forecast of a parameter is expected to require an infinite amount of time and resources. Therefore, initially, our model will be based on a rough estimate, then we will pay more attention to the estimation of the variables which play a key role in calculating the final result by using the results of the sensitivity analysis.

In view of the above, when conducting the sensitivity analysis, we should not assume identical diversions in the case of each input parameter. The expected values of input variables are often changed by $a+/-1-10 \%$ value uniformly. Although this method could provide help in the estimation of a kind of elasticity indicator and be used for further analyses, it is usually not used for this purpose. The comparison of the mere effects on the result is an explicit error. Namely, the aim is not to examine raw changes, as the distribution of the individual input parameters around the expected value is not even at all.

In the case of a sensitivity analysis, the correct solution is when the expected minimum and maximum values of a given variable are used as substitutes in 
a model when examining the effect. In this way, it becomes clear how serious a mistake we commit if we do not use the correct expected value. No analyst tends to suppose that the chance of a $1 \%$ shift is the same for example in the case of an expected inflation rate of $3 \%$ and estimated revenue of HUF 1 billion. When this question is raised, it often comes to light that analysts expect the inflation rate to be between $2 \%$ and $4 \%$, while the revenue between HUF 900-1100 million. Based on the above, in the case of the former, they can even image a difference of $+/-33 \%$, while regarding the latter, the tolerance is merely $+/-10 \%$.

This may explain the third typical error in practical applications. Users often confuse the meanings of percentage and percentage point. Consequently, in sensitivity analysis, they use $2 \%$ and $4 \%$ as substitutes for inflation, while HUF 990 million and HUF 1010 million as substitutes for revenue. However, in this case, the comparison of absolute diversions in the final result makes hardly any sense. This example indicates why it would better to normalise with the applied diversion and calculate elasticity indicators.

Moreover, Koltai (2015) also draws attention to the fact that the correctness of a sensitivity analysis also depends on the structure of the model. Instead of the simple analytical method, the use of the simplex method or perturbation analysis might be required, as well.

\section{SCENARIO ANALYSIS}

In the course of scenario analysis, some input variable combinations describing possible versions of the future are written in the model. This analysis aims to examine how a specific project or company will perform in different environment, therefore the risk of the strategy is analysed instead of the risk of the model.

Barakonyi (1999, Chapter 3) provides a detailed and practical description of scenario analysis. The author highlights: this method requires the development of scenarios which, inter alia, 1) describe possible future states in a 2) consistent and 3) credible manner, while 4) providing alternatives. Due to 5) relatively high probability, the 2-4 developed scenarios cover the majority of expected events.

According to this approach, with the involvement of several corporate professionals with different background and by means of e.g. brainstorming, it is worth mapping possible future corporate events, then preparing scenarios from some of the most probable trends. Eventualities which are not included in scenarios due to their low probability should not be rejected either: corporate risk management should prepare consciously for them. 
In the light of the above, during scenario analysis, setting up "optimistic", "normal" and "pessimistic" scenarios, which are so widespread in practice, is out of question [Lukic (2017)]. An economic situation (extreme output) in which all the parameters which are critical in terms of the plan have the least or most favourable values is extremely improbable. Such situations are not only rare, but they are also impossible and inconsistent in most cases: the economic boom and the increase in demand can be advantageous for a company, but the increasing market competition and the rising wages are disadvantageous. Based on the above, when developing scenarios, the usual simultaneous movement of parameters as well as economic logic have to be considered.

Of course, after the development of scenarios and using them as substitutes in models, the most favourable, i.e. the most optimistic version is revealed. However, at this point, it is not worth renaming the scenarios. During their creation, they should rather be named based on the market and internal processes they describe.

Another mistake is when scenarios are used instead of discrete alternatives: e.g. if the two examined cases differ from each other only regarding the volumes to be sold in the following years, we should rather use a multiple-period sensitivity analysis than a scenario analysis. Such calculations are very important, but they have to be used in the course of the analysis of a specific scenario.

Dividing the whole sample space according to scenarios may result in errors, as well. Three or four alternatives can hardly describe reality, however, if we involve extreme events and values, we might forget appropriate risk management. If, notwithstanding the above, we intend to describe the entire reality by means of only a few cases, we should take care of including the whole expected set of values and distribution of all input parameters jointly in the cases examined.

\section{MONTE CARLO SIMULATION}

The point of Monte Carlo simulation is that it generates individual realisations for each of the appropriately selected input variables based on the distribution characteristics of the given scenario, then records the values of result variables by using the received combination as a substitute in the model. By repeating the process multiple times (usually at least ten times), not only the expected values of result variables, but also their distribution can be predicted and analysed. At the same time, as this procedure requires the estimation of multiple parameters, the risk arising from the accuracy of input data may be higher, therefore our results may be distorted.

Unfortunately, it is easy to find practical examples for the four modelling errors mentioned by Barakonyi (1999:82) in this case, as well. Monte Carlo simulations 
which change the value of only 2-3 variables based on random normal distribution, as well as company assessment models assuming perpetual operation even in the case of inappropriately selected forms of distribution (calculations resulting in negative share values) or with persistently lower profitability than the expected return are quite frequent, as well.

In the case of such tasks, it is important how well the change of input variables can be reflected in the given environment. The contiguous distributions used in simulations are almost always symmetrical, in line with our observations and the limits of the given computer application. McLeay and Azmi (2000) draw attention to the fact that the usual formulas of different financial indicators show rather asymmetric, skewed and pointed distributions, therefore it might be appropriate to transform them, because the categorisation models built on them are sensitive to violating normality in most cases. Based on the results, their solutions are more effective if the various extreme values are omitted, as more information content remains available.

It is also possible that we ourselves have to own the correct distributions, as the selected spreadsheet has no built-in tool for that move. For example, LinaresMustarós et al. (2013) suggested using fuzzy logic, which is not available directly in most programmes, for estimating corporate liquidity problems. They point out: this approach provides a practical estimate of the frequency of payment difficulties and, with some learning, this approach can be easily adapted to the models of spreadsheet programmes widely used in corporate environment, as well.

On the other hand, Wang et al. (2010) emphasise that the Monte Carlo simulation cannot be a remedy for all problems, either. The results of traditional simulation usually reveal very little about extreme (low probability) events. Moreover, in the case of certain outputs, the partial effect of affecting factors is very difficult to decrypt, as well. The auxiliary calculation suggested by us helps to remedy the errors without significantly increasing the calculation needs of the Monte Carlo simulation. Fiáth et al. (2013) also refer to a similar use in Hungarian domestic practice.

Risk analysis has several other alternative approaches, as well. E.g. according to Li et al. (2018), the only proper method for the calculation of corporate financial risks is the combination of multi-level fuzzy logic with quantitative analysis. Subjective and objective rankings were applied simultaneously, and then they were combined with the TOPSIS method. At the same time, Nowak (2005) suggest using the Promethee II method, which processes qualitative and quantitative information simultaneously, for the assessment of investment projects, by combining it with simulation results and the principles of stochastic dominance, adding expert opinions. 
Such approaches may provide a more accurate result in laboratory conditions, but neither the knowledge imparted in the framework of usual specialised bachelor studies, nor the software support usually available in corporate environment is enough for their everyday use. Consequently, the aforementioned research and similar studies reduce only the uncertainty about the selection of the model, while they might even increase the risks arising from input data and the users of the model.

\section{SUMMARY}

In the financial modelling process, three risk sources can be identified. The errors may be due to the person of the modeller (lack of sufficient knowledge and resources, motivational and ethical problems), the characteristics of the model (incorrect or simplistic assumptions and relations), as well as the erroneous estimation of the values of input parameters. Usual means of risk analysis focus only on the source of the latter error, however, a good corporate risk management system should reduce the effect of all of three factors, e.g. by setting up an analytics team whose members can control each other's work, prescribing the concurrent use of alternative models and providing continuous training.

Out of the tools for reducing the risks posed by models, the article dealt with sensitivity analysis, scenario analysis and Monte Carlo simulation in detail. Although these methods are well-documented in Hungarian language, unfortunately, their application is often incorrect.

Professional literature also points out that the simplest form of these methods does not necessarily lead to the best result. On the other hand, complex models describing reality more accurately may be more sensitive to the estimate accuracy of input data (perhaps require data which are very difficult to acquire) and may pose a special challenge regarding the person of the modellers, as well. Therefore, their application might even increase of the aggregate risk of modelling. 


\section{REFERENCES}

Adamczyк, Piotr - Zbroszczyk, Agnieszka (2017): Business Valuation - Practice of domestic WSE members in 2016. Zeszyty Naukowe Uniwersytetu Szczecińskiego. Finanse, Rynki Finansowe, Ubezpieczenia, 89(5), 233-249, DOI: 10.18276/frfu.2017.89/2-17.

BARAKonyi Károly (1999): Stratégiai tervezés: Stratégiaalkotás I. [Strategic planning: Strategy Building I.]. Budapest: Nemzedékek Tudása Tankönyvkiadó, 240 p.

Beaman, Ian -Waldmann, Erwin - Krueger, Peter (2005) The Impact of Training in Financial Modelling Principles on the Incidence of Spreadsheet Errors. Accounting Education, 14(2), 199-212, DOI: 10.1080/0963928042000229699.

Ferenczi Zoltán (2006): Operációkutatás [Operational Research]. Győr: Széchenyi István Egyetem, http://www.sze.hu/ kundi/opkut_jegyzetek/Oper\%E1ci\%F3kutat\%E1s.pdf (downloaded:2020. január 19.).

Fiáth Attila - Nagy Balázs - Tóth Péter - Dóczi Szilvia - Dinya Mariann (2013): Egységes kockázatkezelési módszertan kialakítása a villamosenergia-ipari átviteli rendszerirányító társaságnál [Development of a Standard Risk Management Methodology at MAVIR Hungarian Independent Transmission Operator Company Ltd.]. Vezetéstudomány, 44(1), 49-62.

Koltai Tamás (2015): Érzékenységvizsgálat termeléstervezési és termelésütemezési modelleknél [Sensitivity Analysis in Production Planning and Production Scheduling Models]. Theses of a Doctoral Treatise at the Hungarian Academy of Sciences, http://real-d.mtak.hu/778/ (downloaded: 2020. január 19.).

Li, Dan-Ping -Cheng, Si-Jie -Cheng, Peng-Fei -Wang, Jian-Qiang -Zhang, Hong-Yu (2018): A Novel Financial Risk Assessment Model for Companies Based on Heterogeneous Information and Aggregated Historical Data. PLoS ONE 13(12), 1-25. DOI:10.1371/journal.pone.0208166.

Linares-Mustarós, Salvador - Ferrer-Comalat, Joan Carles - Cassú Serra, Elvira (2013): The assessment of cash flow forecasting, Kybernetes, 42(5), 720-735. DOI: 10.1108/K-03-2013oo6o.

Lukic, Zoran (2017): The Art of Company Financial Modelling. Croatian Operational Research Review 8(2), 409-27. DOI: http://hrcak.srce.hr/crorr?lang=en.

Mcleay, Stuart - Azmi, Omar (2000): The Sensitivity of Prediction Models to the Non-Normality of Bounded and Unbounded Financial Ratios. The British Accounting Review 32(2), 213-30. DOI: 10.1006/bare.1999.0120.

MÉRő KATALIN (2018): A kockázatalapú bankszabályozás előretörése és visszaszorulása - Az ösztönzési struktúrák szerepe [The Increasing and Decreasing Importance of Risk-Based Bank Regulation - The Role of Incentive Structures]. Közgazdasági Szemle, 65 October, 981-1005. DOI: $10.18414 /$ KSZ.2018.10.981.

NowaK, Maciej (2005): Investment Projects Evaluation by Simulation and Multiple Criteria Decision Aiding Procedure. Journal of Civil Engineering \& Management 11(3), 193-202. DOI: 10.1080/13923730.2005.9636350.

Sener, Salci - Jenkins, Glenn P. (2016): Incorporating Risk and Uncertainty in Cost-Benefit Analysis. Development Discussion Papers, http://search.ebscohost.com/login.aspx?direct=true\&db $=$ edsrep\&AN=edsrep.p.qed.dpaper.291\&site=eds-live.

Wang, Yu -CAO, ZIJun -Au, SiU-Kui (2010): Efficient Monte Carlo Simulation of Parameter Sensitivity in Probabilistic Slope Stability Analysis. Computers and Geotechnics 37(7-8), 1015-22. DOI: 10.1016/j.compgeo.2010.08.010. 